\title{
The Beginning of the End for the Chinese Proletariat
}

\author{
BO ÆRENLUND SØRENSEN
}

\begin{abstract}
This article examines how China's Communist Party (CCP) sought to justify its policies fostering inequality at the urban factory floor in the early years after Mao's death through publications in the People's Daily. The article focuses on three issues that emerged frequently in the newspaper: the increased prevalence of incentive wages, the abolishment of life-time employment for workers and the evolving discourse related to worker influence at their workplace. The article shows that the People's Daily did not simply seek to persuade the public that the reforms were compatible with socialism, the newspaper also took great care to showcase which kinds of behaviours and emotions would be appropriate for the new working subject. The CCP's dedication to reforming the population through the press makes the People's Daily an excellent source for tracking norm intransigence on the part of the population. Based on the observation that the CCP sought to legitimate policies ending employment security many years before such policies were adopted, the article also suggests that public opinion had a direct influence on the timing of the early reforms.
\end{abstract}

Keywords: media, post-Mao economic reforms, People's Daily, incentive wages, employment security

This article examines how China's Communist Party (CCP) tried to legitimate those policy changes that directly affected China's urban workers in the early years after Mao's death in 1976. ${ }^{1}$ Legitimation was a particularly important problem for the CCP at this time. The Party had not only lost its charismatic Chairman, it had also presided over ten years of 'Cultural Revolution' (1966-1976) with state-abetted

This article can be accessed at https:/ / doi.org/10.22439/cjas.v38i1.6061. 
violence, shifting political campaigns and widespread disruption of urban social services. Moreover, many of the most experienced and popularly-respected leaders had died or been removed from office during this period. Mao's hand-picked successor, Hua Guofeng, was unknown among the broad public and had few senior connections. Taken as a whole, China's economic growth had been unimpressive since 1957, not least compared to the countries on China's periphery who were quickly building up a modern industrial base and integrating with the globalising economy (Naughton 2007). Unless its industrial competitiveness could be improved, China seemed destined to fall even further behind.

When it came to industrial upgrade, the party-state would have to rely on its own abilities to reform. The Chinese party-state had nationalised almost all industry in the 1950s and replaced the labour market with an allocation system under which the party-state assumed responsibility for dispatching personnel to every major urban workplace across the country. These workplaces provided their workers with the major social reproduction services, including food, housing, health care, schooling, ideological infotainment, pensions, cremation and so forth (Andreas 2019; Dillon 2015; Frazier 2002). Chinese peasants, on the contrary, did not receive fixed salaries, nor were they offered much social service apart from primary education. This article focuses on the situation for China's urban proletariat, the class of people who, according to decades of propaganda, possessed the highest consciousness of any social class.

Improving industrial productivity would not be easy. First of all, the chaos of the Cultural Revolution had seriously weakened the faith of many Chinese citizens in the CCP. Second, the urban working class, which had been adulated by state propaganda and mobilised to fight against the bureaucracy during the Cultural Revolution, had developed 'a newfound pride in their proletarian status as well as a powerful language of class with which to challenge unwelcome policies' (Perry and Li 1997: 193). The Chinese state did not, however, possess the foreign capital necessary to import labour-saving equipment, so improving productivity would have to centre on reorganising production and strengthening the motivation of the workforce, who seemed very well positioned to resist changes that might hurt its interests. In terms of motivating the workforce, three challenges seemed particularly prominent: increasing worker motivation; doing away with worker assumptions of absolute job security; decreasing 
the expectation among workers that their supposedly revolutionary consciousness gave them a role to play in the management of their workplace.

When it came to increasing motivation, one way might have been to use material incentives, but this had proved problematic for the CCP on earlier occasions. Mao and his allies had always preferred to motivate workers through the power of example, urging local, regional and national leaders to appoint particular individuals as 'model workers' whose superior exploits were held up for others to emulate (Farley 2019). This had been the primary strategy in the periods when the more left-leaning individuals on the Politburo had been most powerful, while leaders such as Liu Shaoqi and Deng Xiaoping had favoured material incentives. Over the years, the prestige of the proletariat and social norms favouring relative equality meant that China's stateowned enterprises (SOEs) had developed a comparatively undifferentiated wage structure (Riskin 1987). In many factories, senior workers drew higher wages than technicians and managers, and worker wages were generally pegged to seniority, number of dependents and political attitude, rather than to education, skill-level or effort (Frazier 2002). In the heady days of the early Cultural Revolution (1966-1967), activist workers in many factories managed to abolish pay differentials all together and to extend permanent positions to those originally hired as temporary workers (Frazier 2002: 230ff.). For the post-Mao reformers, incentive pay might not have been the answer they were looking for.

The second challenge for the party-state was that SOE workers expected to hold on to their position for life, even staying in their factory-owned apartments into retirement, where distributing their benefits also befell their former employer (Dillon 2015). During the Cultural Revolution, the strength of workers at SOEs had allowed the informal practice of dingti-making worker and cadre jobs inheritable within families - to evolve in many factories. This points to the third challenge for would-be reformers. While the highest political leadership was weak and enjoyed limited legitimacy after Mao's death, workers enjoyed high prestige and had recent experience with taking arms to defend their interests. As we will see below, these factors generated a pressure to formalise worker influence at their workplaces, something that had not been seriously considered since the early 1950s (Frazier 2002). In short, reformers faced three issues in particular: wage incentives might not have necessarily been effective means of increasing motivation; neither the formal system nor the expectations of workers 
would have accommodated layoffs; workers enjoyed social prestige and expected to wield influence over decisions at the factory floor.

Based on this context, this article examines what the main party newspaper, the People's Daily, wrote about labour reforms in the early years after Mao's death. Faced with all of these obstacles, how did China's post-Mao reformers attempt to legitimate the policies that would in three decades change the situation for most of China's urban proletariat from life-long employment and equal wages to extreme precarity and vast income differentials?

\section{Party-state Media}

Previous examinations of how the early reforms were discussed in the party-state media have reached different conclusions. Some scholars have argued that the new policies were their own most important legitimation because workers were living lives of such material misery that they could not but welcome reform (Kroeber 2016). Others have focused on the ability of the CCP to persuade the workers that the reforms were of a socialist nature, thereby depriving them of their ability to unite against them under the banner of socialism (Kluver 1996; Sun 1995). Yet, others focused almost exclusively on what the People's Daily reveals about disagreement on the Politburo, and did not interrogate the newspaper for what it reveals about public sentiment (Weatherley 2006; Vogel 2011).

Building on insights from the above examinations, this article takes a somewhat different approach by examining contemporaneous articles in the People's Daily to see how the reformist leadership used the People's Daily as an integral part of the reforms. As the analysis will show, by examining how the reformist leadership used the People's Daily as a part of the reform efforts - rather than reading the paper primarily as disingenuous rhetorical trickery or as a battleground for Politburo factions - we become able to see how the People's Daily is a valuable source for understanding the evolving relationship between China's workers and the political leadership in this period.

Research for this article relies on publications in the People's Daily in the years 1976-1988. The People's Daily has generally been considered, by ordinary Chinese and international scholars alike, to be the mouthpiece of the CCP's leadership (Shambaugh 2007). In the late 1970s and into the 1980s, all of China's enterprises had to subscribe to the People's Daily, and articles in the People's Daily had, for decades, been used 
in the mandatory after-hours study meetings at factories, particularly during the periods of intense top-down political mobilisation. We do not have much information on what ordinary workers in the 1980s thought about the People's Daily, but the CCP leadership put enormous emphasis on influencing the citizenry through its control over media and other cultural products (Shambaugh 2007; Volland 2003). Therefore, the paper is a crucial source of information about how the partystate sought to influence public opinion (Fang 1994; Fang 2001; Link 1992; Wilson 1991).

In terms of analytical framework, this article relies primarily on the work of Quentin Skinner (2002), who has offered much insight into how anyone wishing to have an effect upon public opinion - 'ideological innovators,' as Skinner dubs them - must necessarily situate their arguments in relation to existing norms, morality, ideology, the social environment, the political past and the contemporary configuration of power relations. In short, what Skinner (2002) highlights is that when ideological innovators seek to change public opinion they very often face entrenched norms which they can only hope to change by staying within the normative boundaries they subtly attempt to rework. In order to properly read the People's Daily of this period, it is necessary to understand that the party-state enjoyed very strong control over the circulation of information. It is also important to note that the partystate had a long history of omitting, altering and fabricating news stories to suit its interests. Therefore, the People's Daily needs to be read 'against the grain'.

In order to select the articles to be included in the analysis, I started by selecting five key terms I assumed would be of relevance: workers, socialism, reform, wages and lay-offs. ${ }^{2}$ I searched for each of these five in the digitised database of the People's Daily in the period 19761988. I then searched for each term in conjunction with the term 'model worker' (laodong mofan) as I knew that the party-state media had often published stories about model workers as a means of educating the public. Whenever I came upon a word or phrase that seemed to be particularly important, I entered it into my spreadsheet as a candidate for further scrutiny. This came to include words and concepts that seemed to change their meaning over time (e.g., individualism, 'remuneration according to work'), notions and places and people that were or had been condemned for various reasons (e.g., Wei Jingsheng, Democracy Wall, Li Lisan), metaphors that somehow stuck out by being unusual (e.g., 'shock troops of the new long march'), words mentioned with 
particular frequency (e.g., democracy, fairness) and words which I knew from the relevant literature would be particularly sensitive (e.g., strike, workers' movement, bureaucratism). By continued iteration, I ended up selecting, reading and coding around 1000 articles.

This article comes in three parts, each of which investigates what the People's Daily wrote in the early reform period about the three particularly onerous labour issues discussed above. The first part examines how the People's Daily framed the topic of worker motivation. The second part examines how the newspaper discussed the need to abolish life-long employment. The third part examines discussions of worker influence at the workplace. What emerges from these investigations is that the party-state paid enormous attention to altering the norms and expectations of the urban proletariat. It also becomes clear that the need for some of the reforms - in particular the need to abolish life-long employment-was voiced repeatedly in the People's Daily long before any such policies were implemented. This, as will be discussed below, shows that the party-state was so wary of resistance from its workforce that it delayed its reforms in response. Finally, the article demonstrates how seriously the People's Daily took its attempts to soften and shape popular norms so as to align these with the party-state's evolving policies. On this basis, the article shows that the Chinese state-led media can profitably be used to draw a topography of norm intransigence on the part of the general population.

\section{How to Motivate China's Urban Workforce After Mao}

When it came to ways of motivating China's urban workforce, the $\mathrm{CCP}^{\prime}$ s new leadership under Hua Guofeng focused initially on emulating the strategies associated with Mao Zedong's leadership. This consisted of arranging local 'labour competitions' (laodongjingsai), the winners of which would then be selected as model workers and their exploits held up for imitation in the media. Such competitions had been widely used by the CCP in the 1940s and 1950s (Yu 2015), and the new leadership apparently nourished great hopes that the reintroduction of competitions would spur worker productivity, as reflected by the fact that the People's Daily published no less than 398 articles making mention of labour competitions in 1977.

These articles highlighted the achievements performed during such competitions, which, according to the People's Daily, were usually organised by model workers and embraced wholeheartedly by 
everyone. During such competitions, the People's Daily claimed, some workers had dedicated themselves to production with such vigour that they were already fulfilling their quota several years into the future. The repeated emphasis that competitions were popular among the workers and that they were organised by workers rather than by their leaders, along with the fact that stories about competitions almost disappeared from the People's Daily a few years later, suggest that they were neither effective nor popular ways of stimulating productivity.

Perhaps in recognition that the labour competitions did not greatly encourage productivity, the People's Daily soon began to publish stories touting the desirability of tying wages more closely to performance. These articles all focused on the concept of 'distribution according to labour' (anlaofenpei), which had been written into the Chinese Constitution in 1975 when the more left-leaning leaders in Shanghai had to compromise with the more industrial-oriented leaders in Beijing (Cohen 1978). 'Distribution according to labour', the People's Daily emphasised again and again, originated in Marx's 'Critique of the Gotha Programme' where it was put forward as a characteristic of society in the initial phase of socialism.

Unsurprisingly, the People's Daily never contextualised why Marx had put forward 'distribution according to labour' as a step towards realising socialism. In Marx's time, the concept had been revolutionary because it served to make the point that workers should be entitled to the full value of their labour, and that the owners of capital did not deserve rent merely because they owned the means of production. In China in the 1970s, however, the phrase did not mean that the factory owner (i.e., the state) should not reap the surplus value, but instead, that salary should be pegged to work performance. With its impeccable socialist imprimatur, the formulation was well suited to make the point that workers should be rewarded materially for working harder. That the CCP considered the phrase to possess great, potential usefulness is attested to by the fact that the party-state leadership devoted no less than four major conferences to exploring the meaning of the term 'distribution according to labour' between April 1977 and October 1978 (Tomba 2001: 25). In addition, the phrase appeared in the People's Daily in 261 and 337 articles in the years 1978 and 1979, respectively.

While it may thus seem that the Hua leadership was quick to adopt both the 'labour competition' approach and the 'material incentive' approach to stimulating its workforce, a closer look at the published articles reveal that there was still considerable unease among the 
party-state leadership regarding the topic of material incentives. While the party-state clearly threw its weight behind pegging salaries more closely to work performance from the beginning of 1977, the People's Daily repeatedly criticised local factory leaders for issuing performancebased bonuses. Distributing such bonuses was, the People's Daily stressed, not the same thing as 'distribution according to labour'. Rather, such bonuses were 'material incentives' (wuzhi ciji), a distinctly negative term in Chinese, and amounted to putting 'bonuses in command' (jiangjin guashuai), playing on the late Chairman's injunction to let 'politics be in command' (zhengzhi guashuai). ${ }^{3}$

This somewhat inconsistent approach only found expression in the People's Daily for a few months, and from April 1977, the People's Daily no longer referred to bonuses as 'material incentives'. It was, it seems, necessary to think matters over. Less than a year later, in February 1978 , an article suddenly stated that referring to performance-based bonuses as material incentives was a way of thinking that must be eradicated. ${ }^{4}$ That this volte face had the highest political backing was made clear later that month when Hua Guofeng voiced clear support for performance-based bonuses in his government work report (Foreign Broadcast Information Service 1978). In the latter half of 1978, the People's Daily published many articles asking whether material incentives were really that bad. That the $\mathrm{CCP}^{\prime}$ s leadership was not entirely comfortable with making this point can be seen from the fact that the term 'material incentives' was soon replaced with the more circumspect terms 'material reward' (wuzhi jiangli) and 'material encouragement' (wuzhi guli). Only one year later, the People's Daily stopped using these terms, and since then the distribution of performance-based bonuses has primarily been described as 'bonuses' (jiangiin).

With the decision of the CCP leadership to embrace material incentivisation, we see, as in previous decades, that some workers were able to exert strong pressure on their local factory leaders or workshop foremen to have the bonuses distributed equally. The headline of an article in November 1978, succinctly conveyed the party-state's dissatisfaction with this situation: 'Distributing bonuses equally to everyone is unreasonable'. ${ }^{5}$ Over the following years, the People's Daily repeatedly made the point that bonuses should be issued to those who worked hard, rather than being divided among all workers. The People's Daily criticised this practice as 'egalitarianism' (pingjunzhuyi) in hundreds of articles in the period from 1979-1984, and in a further move to ensure that bonuses in fact came to stimulate productivity, new rules were 
issued to tie the size of bonuses to an enterprise's profits (Tomba 2001: 66ff.).

The distribution of bonuses quickly provoked normative intervention by the People's Daily against individuals transgressing the ascetic norms propounded by the party-state for decades. One article from March 1979 stated that 'Some people have erroneous ways of thought, and they lavish away their bonus money on eating and drinking' ${ }^{6}$ Through the 1980s, the People's Daily continued to highlight that people should not spend their money on trivialities such as banquets and binges (dachidahe). In the early 1980s, public unease about the growing wealth gap also brought the People's Daily to produce articles stressing that those who were doing well under the reforms deserved respect, but were instead subjected to theft and beleaguered by loan-seekers. ${ }^{7}$ This topic was repeated many times in 1983-1984, usually described as people with 'red-eye disease' (hongyanbing) - a colloquial metaphor describing jealousy as a disease-treating those who 'dared to stick out' (maojianhu) unfairly.

In its attempts to delineate the proper ways of spending money and to alter public norms to fit with the reform agenda in ways both conducive to social stability and the emerging pattern of economic growth, the People's Daily began to increase its focus on another practice intimately connecting money and morality, viz., philanthropy. An article from 1982 detailed the experiences of a distillery worker who exposed how local cadres routinely commandeered large amounts of liquor. The People's Daily reported that the problem had been resolved, and the worker was awarded both a model worker title and a 100 yuan prize, which he donated in full to the distillery's nursery. ${ }^{8}$

In another account involving philanthropy, a man who had contracted a company ${ }^{9}$ had done so well that the authorities awarded him a model worker title as well 1,000 yuan, which he donated to his company's nursery..$^{10}$ Judging by the People's Daily, it became increasingly common for people who received monetary awards to donate these to public organisations. If we examine who received these donations, we find that recipients were nurseries, elementary schools, the China Children and Teenagers' Fund and a government-run educational amusement park known as the Children's Palace. ${ }^{11}$ In other words, bonuses and awards were presented by the People's Daily as morally legitimised through philanthropy with distinct paternal overtones; a storyline which would become more prevalent in subsequent decades. 


\section{How to Abolish Life-long Employment}

Alongside the efforts of the People's Daily to alter worker norms and expectations in relations to remuneration, in 1979 the party-state began to invest considerable efforts into denigrating the notion of life-long tenure. This happened through a barrage of references to smashing the 'iron rice bowl' (tiefanwan) - a term used to refer to life-long employment in state-owned enterprises (SOEs) - and to altering the mindset of those who liked 'food from the big pot' (daguofan), a negative term used to denote people who enjoyed the fruits of collective effort without making proportionate contributions. While these colloquialisms had been in common use for decades, they had seldom appeared in the press before 1979, when the People's Daily began to print articles claiming that many readers had written to the newspaper demanding the abolition of the iron rice bowl, because this kind of employment surely made people lazy. ${ }^{12}$ In 1981-82, the laziness supposedly induced by eating from the big pot came to be connected with the national economic difficulties of those years. ${ }^{13}$

In 1983, the People's Daily further ratcheted up the campaign to abandon the iron rice bowl, one article quoting a representative at the Shanghai People's Congress on how job insecurity could compel diligence:

At some factories where they have [...] broken the iron rice bowl, some people have developed a 'feeling of crisis' [...] A 'feeling of crisis' is not a bad thing. If a 'feeling of urgency' can develop out of such a 'feeling of crisis', then all the better. An 'iron rice bowl' is very secure, but it brings along with it indolence, exasperating sluggishness, lethargy and perfunctoriness. ${ }^{14}$

Also in 1983, the People's Daily took to employing rhymes to hammer in the message that "the big pan" suckles the lazy Han' (" daguofan" yang lanhan'); a rhyme used in nine articles in 1983-1984 and on special occasions up until 2020.15

As so often in the People's Daily, coverage of international issues was used to send messages about domestic reforms. The fact that worker unrest could be just cause for terminating an employment relationship was clearly signalled in the paper's coverage of the 1981 airportcontrollers' strike in the US. The articles devoted to this conflict were light on denunciations of the hard-bitten approach of the American government, marking a clear contrast with previous coverage of the tribulations of the American working class. The People's Daily even 
went so far as to express sympathy for the problems of the American administration and explained that 'If [Reagan] chooses to make a concession to the airport controllers' union, this will ignite a chain reaction and seriously affect his plans for an economic recovery'. ${ }^{16}$

Preparing the population for the abolishment of employment security, 1978-1979 also marked the beginning of a great increase in stories in the People's Daily about entrepreneurs (qiyejia), self-employed (getihu) and individuals setting up their own businesses (chuangyezhe), all prospering in no time, according to the People's Daily. The People's Daily also began to publish stories praising model workers who voluntarily abandoned their 'iron rice bowls' to start successful businesses on their own. ${ }^{17}$

The first significant step taken towards reforming the labour system was not, however, taken until 1986 when legal changes introduced five-year contracts for new employees at SOEs; leaving workers who were already employed at SOEs unaffected. These changes, along with inflation, were probably among the reasons why 1986 saw a number of labour unrest episodes, including strikes and occasionally even riots in big cities (Baum 1997: 385f.). In 1986, the People's Daily also began to talk about lay-offs in more direct terms. In one case, the head of an electrical machinery factory had been removed from his town's list of model worker nominees and subjected to severe criticism because he had made redundant a number of mid-level managers. The People's Daily made clear that the criticised leader had acted appropriately, and when the paper picked up the case a month later, the leader had indeed been cleared of all criticism and even awarded a model worker prize. ${ }^{18}$

By the latter half of the 1980s, discussions of the political activities or consciousness of China's model workers almost disappeared from the People's Daily. They were replaced by a new kind of subject, the successful entrepreneur. One such article focused on the businesswoman Li Guilian who noted that a boss had to be both a 'loving mother' and a 'strict father', and in pursuit of these ideals she instituted a number of strict rules for her employees, but also made sure that they all received a cake on their birthdays. ${ }^{19}$

The only thing we learn about Li's workers is contained in a small anecdote noting that they produced clothing of exceptional quality, except on one occasion when a worker produced an item of clothing earning a score of only 96 - with 98 being the norm - causing the worker to break down in tears for 'having lost the face to see anyone'. Clearly, while managers were portrayed as parents, the workers were 
cast in the role of children anxious to please. In less than seven years, the image of China's working class presented in the People's Daily had changed from larger-than-life figures of superior political consciousness to timid, childlike creatures. Interviews conducted at the time confirmed that China's workers were acutely aware of their changed public image, one worker noting that after the beginning of reform, 'the social status of workers is very low, and nobody thinks highly of workers. The public opinion and even the leaders hold that workers are rude, uncivilized, disobedient, and unsophisticated in speaking' (Cai 2006: 174).

What made the assault on life-time employment even more remarkable is that the party-state did not begin to lay off workers from the SOEs at this point, and would not do so in any noteworthy degree before the middle of the 1990s. When the party-state took no significant concrete steps in this direction - at least not before the adoption of the Contract Law in 1986, which did not affect workers in existing employment relationships - this was due to the fact that the implicit social contract was very much focused on providing job security. The party-state maintained very cautious labour policies up until the middle of the 1990s in order to keep urban unemployment low (Naughton 2007: 183ff.). This meant that overstaffing at China's SOEs continued to grow until the early 1990s (Dong and Putterman 2001). This is a good example of how the intentions of the party-state-in this case, the intent to lay off workers - could be signalled for years in the stateled press before the party-state found the time ready to introduce its intended policies.

\section{Worker Influence at Workplaces}

The evolving debate over the formalised influence of workers at their workplace presents a particularly interesting case study of how divisions on the Politburo allowed for public debate over the institutional arrangement of formalised power. The fact that workers were considered important by the political establishment was reflected, not least, in the debate over the expansion of workplace democracy. As mentioned above, the Cultural Revolution had infused in many workers 'a newfound pride in their proletarian status', and the weakened position of factory and party leaders - along with a strong fear of new popular upheavals - found concrete expression in the adoption of measures aimed to institutionalise the influence of workers. 
The expansion of worker influence at workplaces came to stand out as an area of particular emphasis after Deng Xiaoping's talk at the national trade union congress in 1978 where he proclaimed that from then on, across the country, workshop directors, workshop section chiefs and workshop group leaders were to be elected by the workers. In addition, all major decisions at the enterprises were to be presented and debated at workers' representatives' congresses, which would also be vested with the authority to recommend that a particular leader ought to be disciplined or fired..$^{20}$ Following this speech, the People's Daily published a flurry of articles in 1979-80, stressing the importance of increasing the power of workers' representative congresses.

At the same time, it was also announced in the People's Daily that model workers were to be 'chosen through public appraisal' (pingxuan). ${ }^{21}$ The term pingxuan - here rendered as "choosing through public appraisal' - did not necessarily mean that model workers would be elected by ballot, but it did signal a considerable degree of grassroots input. That the phrase was sensitive can be seen from the fact that it had not been used in relation to selecting model workers by the People's Daily since 1957, and that it all but disappeared after 1985. It was, however, used in this connection in People's Daily articles every year from 1978 to 1985. The height of enthusiasm over worker input in the selection of model workers occurred in March 1980, when the People's Daily clearly spelled out how model workers were to be selected through popular vote. ${ }^{22}$

Another signal that autonomous worker influence was on the agenda in March 1980 was the posthumous rehabilitation in that month of Li Lisan, the former leader of China's official trade union who had fallen afoul of the rest of the CCP leadership in the early 1950s by advocating for a degree of independence of the labour union from the Party. In the fall of 1980, the People's Daily, in two separate articles, conjoined the terms 'autonomous organisation' (zizhi zuzhi) and 'strike' (bagong) in a positive way. ${ }^{23}$ The only other People's Daily article to ever bring these two concepts together would appear in June 1989, and this time to denigrate the notion that autonomous organisations should involve themselves with strikes. ${ }^{24}$ That workers could be allowed independent organising was further indicated by the positive attention that the actions of the autonomous trade union Solidarity received in partystate discourse (Wilson 1991). By the fall of 1980, it seemed that the expansion of institutions for electoral democracy would become a key part of the post-Mao reforms, and a significant part of the rationale for 
doing this, as explained in the People's Daily, centred on the importance of increasing the power of the working class. And then, momentum shifted.

As early as 1978, the political elite had been troubled by strident criticism of the CCP expressed on big-character posters on what became known as 'Democracy Wall' in central Beijing, but even though the most outspoken critic, Wei Jingsheng, had been arrested, the moves toward expanding democracy had continued apace. What seemed to have caused momentum to shift in the autumn of 1980 were the county-level elections in the fall of that year, where several candidates anathema to the party-state leadership were elected (Womack 1982). Moreover, by the fall of 1980, Deng had established his position of unchallenged authority within the Party, and he thus no longer needed to seek public approval in his attempts to oust Hua from power.

Having decided to curtail parliamentary democracy, the leadership nevertheless felt uneasy about public reactions. This can be seen from the fact that the People's Daily published several articles about problems with electoral democracy abroad before making any mention of elections in China. ${ }^{25}$ Moreover, rather than discussing the controversies surrounding the county-level elections, the People's Daily devoted several articles to explaining that the participation of the grassroots in selecting model workers had caused a number of unworthy workers to be selected. ${ }^{26}$ After this, the People's Daily no longer mentioned grassroots participation in model worker selection, indicating that such a practice was no longer encouraged. The remaining county-level elections were also cancelled, but this was never mentioned in the People's Daily. After 1981, the People's Daily had most often described model workers as 'gushing forth' (yongxianchu); a metaphor serving to elide the manner of their top-down selection.

The next step in the curtailment of workers' rights came in 1982, when the right to strike was eliminated from the state constitution (Jones 1985). The first article to mention this was printed in May 1982, and consisted of a terse, untitled report informing readers that model worker representatives unanimously endorsed abolishing the right to strike. ${ }^{27}$ In the accompanying photograph, three model workers stooped over large pieces of paper, presumably the draft constitution. Of the two figures in front, one was inspecting the documents, while another was writing something down, metonymically allowing model workers a hand in the drafting of the constitution. The third person looked sternly into the camera, signalling his support of the constitutional amendment. 


\section{Conclusion}

The article has demonstrated that the People's Daily did not simply attempt to alter the interpretation of what socialism was supposed to be, though this was certainly a part of its strategy. Instead, the People's Daily attempted to alter the norms, expectations and behaviour of the individuals affected by the increased reliance on material incentivisation. It has also become clear that the efforts of the party-state reformers to dismantle the expectations of life-long employment occupied a great deal of column space from the late 1970s until the latter half of the 1980s. While this media campaign was prominent from 1980, labour redundancy in Chinese SOEs only shot up during the 1980s and into the early 1990s (Dong and Putterman 2001), even though a bloated workforce and escalating pension payments made it increasingly difficult for SOEs to compete both domestically and internationally. This illustrates how popular norms had served to constrain the opportunities available to the reformers, as well as how the party-state had attempted to use media campaigns to prepare the populace for intended reforms.

The People's Daily's coverage of the formalisation of worker influence at their workplace shows that Deng Xiaoping was eager to associate himself with the expansion of electoral democracy. When Deng no longer needed popular support against his competitors on the Politburo, and when it turned out that the electorate would sometimes return representatives anathema to the party-state, the party-state moved swiftly to end the democratic experiments. This decision was apparently too sensitive to be discussed directly in the People's Dai$l y$, which instead attempted to delegitimise popular voting as a useful mechanism of selection by describing electoral problems abroad combined with descriptions of how workers were wont to elect the wrong people among themselves to serve as model workers. This illustrates how the People's Daily sometimes attempted to convey messages through indirection.

In conclusion, the People's Daily is not only a useful source for examining how the Party endeavoured to alter public perceptions of workplace relations proper to socialism. More importantly, the paper also attempted to modify popular norms and expectations to suit the evolving exigencies of the reforms. Where most previous studies (Kluver 1996; Sun 1995) have emphasised that the People's Daily often sought to omit and distort information so as to influence popular perceptions, 
I have argued that the People's Daily also expressed the party-state's strong belief in its own ability and duty to mould the thoughts and habits of the citizenry. In this respect, the party-state not only attempted to shape the population to fit its policies, but also sometimes diluted or delayed its policies so as to fit popular norms and expectations.

In the period since the 1980s, the PRC media landscape has grown increasingly complex. Most citizens have access to a wide array of information sources, though the vast majority of these are under the control of the party-state. The People's Daily continues to function as the official voice of the CCP, but its reach and influence has diminished significantly. With the deepening of reform in the early 1990s, the People's Daily began to make new distinctions between different kinds of workers. The term previously used most frequently to refer to workers (gongren) was supplemented by the terms 'peasant worker' (mingong and nongmingong) and 'temporary worker' (dagongzhe). These new terms were useful because they made it possible to talk about the rapidly increasing number of migrant workers as a category distinct from the previously honoured working class. In general, issues pertaining to workers, including migrant workers, have appeared with diminishing frequency up through the period of reform, which has seen a significant, albeit fluctuating, number of labour disputes since the middle of the 1990s. Individual cases of labour disputes have made it into the People's Daily, but usually only after local authorities have intervened, thus serving to send the message that the party-state protects migrant workers from the unpredictable fluctuations of the labour market and from 'rotten' employers.

The People's Daily has continued to print a substantial, although gradually declining, number of stories celebrating model workers for their unselfish industriousness. Since the 1990s, model workers have frequently been commended for their ability to adapt to changing job market demands and opportunities. Stories about model workers have come to focus on things unrelated to work, such as joyous family holidays, national sports events, the celebration of PRC martyrs and the socio-political issues of the day. For instance, the most renowned model worker of the 2010s was steel-factory worker Guo Mingyi, who has been the subject of a play, a biography, a biopic and more than 500 People's Daily articles. Guo is most often celebrated for his endeavours to motivate people to become blood donors, at once serving to highlight an important health sector need as well as implying that the best of China's workers give their blood to the nation. 
Overall, the People's Daily published much fewer articles about workers and labour issues in the last decade. That the party-state perceived much less of a need to address such issues through the People's Daily is probably a testimony to the fact that the notion of a united working class with shared privileges and obligations has lost much of its force. The paper continues to make frequent use of the term socialism, but the specific meaning of this term has become increasingly difficult to pin down and it is almost never invoked in reference to particular labour issues. In other words, the party-state has managed to divorce socialism from the proletariat.

BO ÆRENLUND SØRENSEN is a postdoctoral researcher at the University of Copenhagen. His research interests include contemporary Chinese society, modern Chinese history, labour history, comparative literature, media and communication studies, digital humanities and cognitive science. E-mail: pzm221@hum.ku.dk

\section{NOTES}

1 This article is based upon research funded by the Carlsberg Foundation, grant number CF18-0838. I would like to thank both the anonymous reviewers and the editors for their useful comments and suggestions.

2 I agree with Hart and his collaborators that examining key terms is usually a productive way of analysing news stories (Hart et al. 2005). This is particularly true in the Chinese context, because the propaganda system sets great store by controlling the usage of specific words and phrases (Schoenhals 1992).

3 People's Daily, 11 Febraury 1977, p.2, 'Guanxin qunzhong shenghuo de youliang chuantong bu rong jianta'; 25 April 1977, p.1, 'Gaoju mao zhuxi de weida qizhi zou woguo ziji gongye fazhan de daolu - daqing youtian dangwei shuji, geweihui zhuren song zhenming quanguo gongye xue daqing huiyi shang de fayan'.

4 People's Daily, 14 February 1978, p.2, 'Qieshi zhengdun qiye-shixian zengchan zengshou'.

5 People's Daily, 4 November 1978, p.2, 'Pingjun fenpei jiangjin bu heli'.

6 People's Daily, 9 March 1979, p.1, 'Yao ba xinsi fang zai zengchan jieyue yundong shang'.

7 People's Daily, 8 March 1984, p.7, 'Yan dongsheng weihe bu yuan dang laomo?'.

8 People's Daily, 28 May 1982, p.2, 'Kexi de bianhua'.

9 As part of the economic reforms, private individuals could assume responsibility for running a state-owned company for a number of years.

10 People's Daily, 6 March 1984, p.2, 'Chengbao duixian changzhang shoujiang'.

11 People's Daily, 24 January 1982, p.3, 'Daxue xinfing - fasheng zai jianghan shiyou xueyuan de shiqing'; 22 September 1983, p.5, 'Zhong gua ren de zhuiqiu -ji hunan sheng laodong mofan, gaoji nongyishi chen weilin'; 18 October 1984, p.2, 'Xi' an shi zhang tiemin jiangjin juanxian gei shaoniangong'. 
12 People's Daily, 11 January 1979, p.2, "'Zhejiang ribao" kaizhan "tiefanwan" wenti de taolun, zai shehui shang yinqi hen da fanxiang'.

13 People's Daily, 22 April 1983, p.5, 'Ping “daguofan"'. On the economic setbacks of 1981-1982, see Meisner 1996:267f.

14 People's Daily, 19 February 1983, p.1, 'Jinri tan'.

15 People's Daily, 27 January 1983, p.1, “"Daguofan” yang lanhan-silun buneng zai chi "daguofan"'.

16 People's Daily, 6 August 1981, p.6, 'Meiguo jichang tatai zhihui renyuan da bagong yingxiang ju da'.

17 People's Daily, 1 November 1984, p.3, 'Jinri shoudu he ge sheng shiqu baozhi yaomu'.

18 People's Daily, 10 June 1986, p.2, 'Bei modiao de laomo - ji kaifeng dianjichang changzhang zheng zhiyong'; 15 July 1986, p.2, 'Kaifeng shiwei zhichi zheng zhiyong gao gaige "bei modiao de laomo" chongxin dangxuan'.

19 People's Daily, 6 September 1987, p.2, ‘Chenggongzhidao-bufen youxiu nongmin qiyejia fangwenji (xia)'.

20 People's Daily, 12 October 1978, p.1, 'Zai zhongguo gonghui di jiu ci quanguo daibiao dahui shang de zhici'.

21 People's Daily, 16 August 1978, p.1, 'Zai quanguo nongtian jiben jianshe huiyi de jianghui'.

22 People's Daily, 28 March 1980, p.1, 'Fahui laomo de daitou, gugan he qiaoliang zuoyong'.

23 People's Daily, 11 October 1980, p.6, 'Bolan lingdaoren tan guonei jingji xingshi'; 1980.11.12, p.7, 'Yinrenzhumu de bolan jushi'.

24 People's Daily, 3 June 1989, p.1, 'Beijing shi zonggonghui fabiao shengmingyaoqiu qudi "gongren zizhi lianhehui"'.

25 The decision to reverse the democratic reforms was couched in such indirect terms that even the well-informed scholar Brantly Womack, who had written about of the local election controversies in 1980, misread the signals and predicted that China's political authorities would persevere with democratic reforms (Womack 1982).

26 People's Daily, 9 March 1981, p.3, 'Pingxuan “laomo" buyao ding ming'e'.

27 People's Daily, 3 May 1982, p.4, '[No title].'

\section{REFERENCES}

Andreas, Joel 2019. Disenfranchised: The Rise and Fall of Industrial Citizenship in China. Oxford: Oxford University Press.

Baum, Richard 1997. 'The Road to Tiananmen: Chinese Politics in the 1980s' in R. MacFarquhar (ed.) The Politics of China: The Eras of Mao and Deng Cambridge: Cambridge University Press, pp. 340471.

Cai, Yongshun 2006. 'The Weakening of Workers' Power in China' in K. E. Brødsgaard and Y. Zheng (eds.) The Chinese Communist Party in Reform. Routledge, pp. 173-191.

Cohen, Jerome Alan 1978. 'China's Changing Constitution'. The China Quarterly 76: 794-841. 
Dillon, Nara 2015. Radical Inequalities: China's Revolutionary Welfare State in Comparative Perspective Cambridge: Harvard University Asia Center.

Dong, Xiao-yuan, and Louis Putterman. 2001. 'On the Emergence of Labour Redundancy in China's State Industry: Findings from a 1980-1994 Data Panel'. Comparative Economic Studies 43 (2): 111-128.

Fang, Yew-Jin 1994. "Riots" and Demonstrations in the Chinese Press: A Case Study of Language and Ideology'. Discourse $\mathcal{E}$ Society 5 (4): 463-481.

Fang, Yew-Jin 2001. 'Reporting the Same Events? A Critical Analysis of Chinese Print News Media Texts'. Discourse \& Society 12 (5): 585-613.

Farley, James 2019. Model Workers in China, 1949-1965: Constructing a New Citizen. London: Routledge.

Foreign Broadcast Information Service 1978. Daily Report: People's Republic of China. Washington, D.C.

Frazier, Mark W. 2002. The Making of the Chinese Industrial Workplace: State, Revolution, and Labor Management. New York: Cambridge University Press.

Hart, Roderick P., Sharon E. Jarvis, William P. Jennings, and Deborah Smith-Howell 2005. Political Keywords: Using Language That Uses Us. New York: Oxford University Press.

Jones, William C. 1985. 'The Constitution of the People's Republic of China'. Washington University Law Quarterly 63: 707-735.

Kluver, Alan R. 1996. Legitimating the Chinese Economic Reforms: A Rhetoric of Myth and Orthodoxy. Albany: State University of New York Press.

Kroeber, Arthur R. 2016. China's Economy: What Everyone Needs to Know. Oxford: Oxford University Press.

Link, Perry 1992. Evening Chats in Beijing: Probing China's Predicament. New York: Norton.

Meisner, Maurice 1996. The Deng Xiaoping Era: An Inquiry into the Fate of Chinese Socialism, 1978-1994. New York: Hill and Wang.

Naughton, Barry 2007. The Chinese Economy: Transitions and Growth. Cambridge: MIT Press.

Perry, Elizabeth J., and Li Xun 1997. Proletarian Power: Shanghai in the Cultural Revolution. Boulder: Westview Press.

Riskin, Carl 1987. China's Political Economy: The Quest for Development Since 1949. Oxford: Oxford University Press.

Schoenhals, Michael 1992. Doing Things with Words in Chinese Politics: Five Studies. Berkeley: Center for Chinese Studies, University of California. 
Shambaugh, David 2007. 'China's Propaganda System: Institutions, Processes and Efficacy'. The China Journal 57: 25-58.

Sun, Yan 1995. The Chinese Reassessment of Socialism 1976-1992. Princeton: Princeton University Press.

Skinner, Quentin 2002. Visions of Politics. Cambridge: Cambridge University Press.

Teiwes, Frederick C., and Warren Sun 2011. 'China's New Economic Policy under Hua Guofeng: Party Consensus and Party Myths'. The China Journal 66: 1-23.

Tomba, Luigi 2001. Paradoxes of Labour Reform: Chinese Labour Theory and Practice from Socialism to the Market. New York: Palgrave Macmillan.

Vogel, Ezra F. 2011. Deng Xiaoping and the Transformation of China. Cambridge: Harvard University Press.

Volland, Nicolai 2003. The Control of the Media in the People's Republic of China. Ph.D. dissertation, Heidelberg University.

Weatherley, Robert 2006. Politics in China Since 1949: Legitimizing Authoritarian Rule. London: Routledge.

Wilson, Jeanne L. 1991. "“The Polish Lesson”: China and Poland 19801990'. Communist and Post-communist Studies 23 (3): 259-279.

Womack, Brantly 1982. 'The 1980 County-Level Elections in China: Experiment in Democratic Modernization'. Asian Survey 22 (3): 18.

Yu, Miin-ling 2015. Xingsu 'xinren': zhonggong xuanchuan yu sulian jingyan (Moulding 'New People': Chinese Communist Party Propaganda and Soviet Experience). Taipei: Zhongyang yanjiuyuan jindaishi yanjiusuo. 